\title{
Semi-continuous xylitol bioproduction in sugarcane bagasse hydrolysate: effect of nutritional supplementation
}

\author{
Walter Carvalho*, Larissa Canilha, Silvio Silvério da Silva \\ Departamento de Biotecnologia, Escola de Engenharia de Lorena
}

${ }^{*}$ Correspondence:

W. Carvalho

Escola de Engenharia de Lorena

Estrada Municipal do Campinho, s/no

Caixa Postal 116

12.602-810 - Lorena - SP, Brasil

E-mail: carvalho@debiq.faenquil.br
Xylose-to-xylitol bioconversion by Ca-alginate entrapped Candida guilliermondii cells in sugarcane bagasse hemicellulosic hydrolysate was carried out in erlenmeyer flasks using the repeated-batch mode of fermentation. The hydrolysate was supplemented or not with ammonium sulfate and/or rice bran extract at the beginning of each repeated batch. Altogether, six sets of three repeated-batches were carried out, the immobilized cells being reused at the end of each batch. The best results were achieved when the hydrolysate was supplemented with both nutrients in all the three repeated batches, which provided xylitol productions of 25.9, 46.8, $48.7 \mathrm{gL}^{-1}$, productivities of $0.27,0.49,0.51 \mathrm{gL}^{-1} h^{-1}$, and yields of $0.45,0.58$, $0.55 \mathrm{gg}^{-1}$, respectively. In the absence of nutrients, the xylitol production, productivity and yield did not exceed $12.1 \mathrm{gL}^{-1}, 0.13$ $g L^{-1} h^{-1}$ and $0.30 \mathrm{gg}^{-1}$, respectively.

\section{INTRODUCTION}

The use of lignocellulosic materials for ethanol bioproduction has long been envisioned around the world. For instance, only in Brazil, much more ethanol would be obtained from the same amount of sugarcane if the sugar-alcohol producing industries used not only the sugarcane juice but also the sugarcane bagasse as a source of carbohydrates. Together with the conversion of hexose sugars into ethanol, the conversion of pentose sugars into value-added products could benefit the economics of the whole process. In this context, the high amount of xylose present in the sugarcane bagasse could be used for the production of xylitol, a specialty sweetener widely used by food and pharmaceutical industries. Among others, this sweetener presents outstanding organoleptic and anticariogenic properties (Winkelhausen, Kuzmanova 1998), prevents osteoporosis (Mattila et al., 2002), can be consumed by diabetics (Parajó et al., 1998a), and can replace antibiotics in the treatment of otitis (Uhari et al., 2000).

Xylitol bioproduction from sugarcane bagasse hemicellulosic hydrolysate ( $\mathrm{SBHH}$ ) has been a subject of intense research at the Engineering College of Lorena since the late eighties, when the yeast Candida guilliermondii FTI 20037 was selected as a promising biocatalyst (Barbosa et al., 1988). Recently, the use of repeated-batch immobilized cell systems to perform the xylose-to-xylitol bioconversion in SBHH was proposed (Carvalho et al., 2002a). The major benefit brought by using the repeated-batch fermentation mode was the non- 
necessity to grow a new inoculum for each batch, while the major benefit brought by the use of immobilized cells was the ease to recycling them at the end of the batches.

In the present study, the nutritional requirements of the yeast Candida guilliermondii FTI 20037 to perform the xylose-to-xylitol bioconversion in SBHH were assessed using Ca-alginate entrapped cells in repeated-batch mode of fermentation. Low-cost nutrients, namely ammonium sulfate and/or rice bran extract, were added or not to the SBHH at the beginning of the repeated batches and the xylitol productions, productivities and yields were compared.

\section{MATERIAL AND METHODS}

\section{Hydrolysate preparation, concentration and detoxification}

Sugarcane bagasse was hydrolyzed in a $250-\mathrm{L}$ reactor at $121{ }^{\circ} \mathrm{C}$ for $20 \mathrm{~min}$, using $100 \mathrm{mg}$ of sulfuric acid per gram of dry bagasse and $10 \%$ solids loading. The hydrolysate thus obtained was 5 -fold concentrated at $70{ }^{\circ} \mathrm{C}$ under vacuum and, then, detoxified by $\mathrm{pH}$ alteration and active charcoal adsorption (Alves et al., 1998) as follows: $\mathrm{CaO}$ was added to the hydrolysate until $\mathrm{pH} 7.0 ; \mathrm{H}_{3} \mathrm{PO}_{4}$ was added to the hydrolysate until $\mathrm{pH} 5.5$; active charcoal $(2.5 \% \mathrm{w} / \mathrm{v})$ was added to the hydrolysate and agitated at $200 \mathrm{rpm}$ and $30^{\circ} \mathrm{C}$ for $1 \mathrm{~h}$.

\section{Cell immobilization}

A loopful of Candida guilliermondii FTI 20037 cells, maintained on malt extract agar slants at $4{ }^{\circ} \mathrm{C}$, was transferred to $125-\mathrm{mL}$ erlenmeyer flasks containing $50 \mathrm{~mL}$ of medium prepared with xylose $\left(30 \mathrm{gL}^{-1}\right)$, ammonium sulfate $\left(3 \mathrm{gL}^{-1}\right)$ and rice bran extract $(10 \% \mathrm{v} / \mathrm{v})$. The cells were grown at $200 \mathrm{rpm}$ and $30^{\circ} \mathrm{C}$ for $24 \mathrm{~h}$, collected by centrifugation at $2000 \mathrm{~g}$ for $15 \mathrm{~min}$, washed and resuspended in sterile distilled water. To entrap the cells into $\mathrm{Ca}$-alginate beads, an adequate volume of the cell suspension was added to a solution of $\mathrm{Na}$-alginate (Satialgine S1100, Degussa Texturant Systems, France) previously heated at $111^{\circ} \mathrm{C}$ for $15 \mathrm{~min}$. The final concentrations of Na-alginate and cells (dry-weight) were 20 and $6 \mathrm{gL}^{-1}$, respectively. Cell-gel beads $(2.75 \mathrm{~mm}$ in diameter) were produced by dripping this mixture into an $11 \mathrm{gL}^{-1} \mathrm{CaCl}_{2}$ solution, using a $19 \mathrm{G}$ needle and a peristaltic pump. The beads were maintained in the $\mathrm{CaCl}_{2}$ solution for $24 \mathrm{~h}$ and washed with sterile distilled water before being used for the xylose-to-xylitol bioconversions (Carvalho et al., 2002b).

\section{Xylose-to-xylitol bioconversions}

The bioconversions, performed in repeated-batch mode of fermentation were carried out in $125-\mathrm{mL}$ erlenmeyer flasks containing $7 \mathrm{~g}$ of cell-gel beads and $43 \mathrm{~mL}$ of medium. The flasks were kept in a rotary shaker at $200 \mathrm{rpm}$ and $30^{\circ} \mathrm{C}$ for $96 \mathrm{~h}$ and, at the end of each batch, the fermented medium was unloaded, the flasks were re-fed with fresh medium, and the immobilized cells were reused as inoculum for the next batch. Initial cell concentration of $1.4 \mathrm{gL}^{-1}$ and initial $\mathrm{pH}$ of 6.0 were used in all the experiments (Carvalho et al., 2004). The SBHH was supplemented or not with nutrients, namely ammonium sulfate $\left(3 \mathrm{gL}^{-1}\right)$ and/or rice bran extract $(10 \% \mathrm{v} / \mathrm{v})$, at the beginning of each batch, according to the design shown in Table I. Calcium chloride $\left(0.1 \mathrm{gL}^{-1}\right)$ was added to the medium in all the experiments (Carvalho et al., 2002b). In the ex-

TABLE I - Experiments planned to assess the nutritional requirements of the yeast Candida guilliermondii FTI 20037 in SBHH during xylose-to-xylitol bioconversions carried out in repeated-batch mode of fermentation

\begin{tabular}{|c|c|c|c|c|c|}
\hline$\overline{\text { Assay }}$ & Batch & Nutrients & Assay & Batch & Nutrients \\
\hline \multirow[t]{3}{*}{$\overline{\mathbf{A}}$} & $1^{s t}$ & $\mathrm{AS}, \mathrm{RB}$ & D & $1^{s t}$ & $\mathrm{RB}$ \\
\hline & $2^{n d}$ & $\mathrm{AS}, \mathrm{RB}$ & & $2^{n d}$ & $\mathrm{RB}$ \\
\hline & $3^{r d}$ & $\mathrm{AS}, \mathrm{RB}$ & & $3^{r d}$ & RB \\
\hline \multirow[t]{3}{*}{ B } & $1^{s t}$ & $\mathrm{AS}, \mathrm{RB}$ & $\mathbf{E}$ & $1^{s t}$ & AS \\
\hline & $2^{n d}$ & - & & $2^{n d}$ & AS \\
\hline & $3^{r d}$ & $\mathrm{AS}, \mathrm{RB}$ & & $3^{r d}$ & AS \\
\hline \multirow[t]{3}{*}{ C } & $1^{s t}$ & $\mathrm{AS}, \mathrm{RB}$ & $\mathbf{F}$ & $1^{s t}$ & - \\
\hline & $2^{n d}$ & - & & $2^{n d}$ & - \\
\hline & $3^{r d}$ & - & & $3^{r d}$ & - \\
\hline
\end{tabular}

AS: ammonium sulfate $\left(3 \mathrm{gL}^{-1}\right) ; \mathrm{RB}$ : rice bran extract $(10 \% \mathrm{v} / \mathrm{v}) ;-:$ without nutrients 
periments with non-supplemented hydrolysates, sterile distilled water was added to the SBHH in order to standardize the initial concentration of xylose. The rice bran extract was prepared by heating a $200 \mathrm{gL}^{-1}$ aqueous suspension of rice bran at $121^{\circ} \mathrm{C}$ for $15 \mathrm{~min}$. After cooling and centrifugation, the supernatant was used in the experiments.

\section{Analytical methods}

Xylose and xylitol concentrations were determined by HPLC (Carvalho et al., 2002b). Free and immobilized cell concentrations were determined by absorbance at $600 \mathrm{~nm}$ and correlated with the cell dry-weight through a corresponding calibration curve. The liquid phase of the samples taken during the fermentation runs was centrifuged $(2000 \mathrm{~g}, 15 \mathrm{~min})$ and the cells were resuspended in water for the determination of the free cell concentrations. A known mass (accuracy within $0.01 \mathrm{~g}$ ) of $\mathrm{Ca}$-alginate beads taken during the fermentation runs and previously dried with an absorbent paper was dissolved in a $2 \%$ potassium citrate solution under agitation. The resulting suspension was centrifuged $(2000 \mathrm{~g}, 15 \mathrm{~min})$ and the cells were resuspended in water for the determination of the immobilized cell concentrations (Carvalho et al., 2003). Xylitol yield $\left(Y_{P / S}\right)$ was calculated as xylitol produced divided by xylose consumed, while xylitol productivity $\left(Q_{P}\right)$ was calculated as xylitol produced divided by the time taken to finish each batch $(96 \mathrm{~h})$. Specific rates of xylose consumption $[(-1 / \mathrm{X}) \cdot(\mathrm{dS} / \mathrm{dt})]$, xylitol production $[(1 / \mathrm{X}) \cdot(\mathrm{dP} / \mathrm{dt})]$ and cell growth $[(1 /$ $\mathrm{X}) \cdot(\mathrm{dX} / \mathrm{dt})]$ were determined according to the method proposed by Le Duy and Zajic (1973).

\section{RESULTS AND DISCUSSION}

After preparation, concentration and detoxification, the SBHH was used as source of xylose for xylitol bioproduction in the repeated-batch mode of fermentation. Ammonium sulfate and/or rice bran extract were added or not to the hydrolysate at the beginning of each batch. As can be seen in Figure 1, the presence of these nutrients, either one at a time or both together, strongly influenced the xylose-to-xylitol bioconversion by the yeast Candida guilliermondii FTI 20037. The best results were achieved when the hydrolysate was supplemented with both nutrients in all the three repeated batches (Assay A), which provided xylitol productions of $25.9,46.8,48.7 \mathrm{gL}^{-1}$, productivities of $0.27,0.49,0.51 \mathrm{gL}^{-1} \mathrm{~h}^{-1}$, and yields of 0.45 , $0.58,0.55 \mathrm{gg}^{-1}$, respectively.

In the absence of nutrients (Assay F), the best xylitol production, productivity and yield $\left(12.1 \mathrm{gL}^{-1}, 0.13 \mathrm{gL}^{-1} \mathrm{~h}^{-1}\right.$

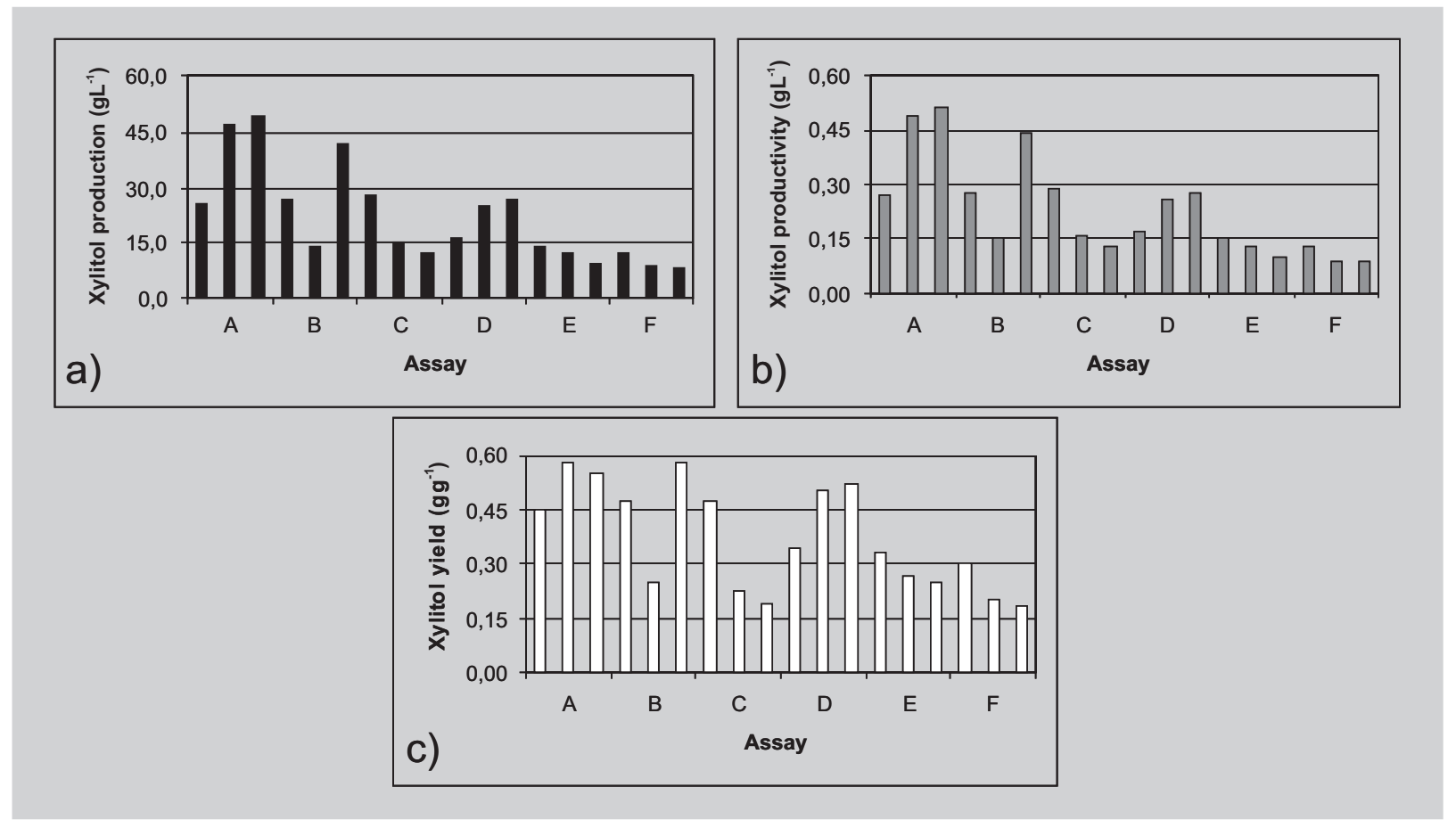

FIGURE 1 - Relative xylitol productions (a), productivities (b) and yields (c) as a function of SBHH supplementation with ammonium sulfate and/or rice bran extract throughout the repeated-batch fermentations. 
and $0.30 \mathrm{gg}^{-1}$, respectively) were observed in the first batch of the series. Afterwards, these response-parameters stabilized or reduced. Hydrolysate supplementation with only ammonium sulfate (Assay E) did not lead to a very different profile throughout the repeated batches. On the other hand, supplementation with only rice bran extract at the beginning of all three repeated batches (Assay D) progressively improved the bioconversion (Figure 1).

The results achieved in Assay $\mathrm{C}$, when both ammonium sulfate and rice bran extract were added to the hydrolysate only at the first batch, were better than those observed in Assay F, when all the three repeated batches were performed in a non-supplemented hydrolysate. Moreover, hydrolysate supplementation with the two nutrients after a cycle in non-supplemented hydrolysate (Assay B) restored the bioconversion parameters to levels similar to those observed in Assay A, when the SBHH was supplemented with ammonium sulfate and rice bran extract in all the three repeated batches (Figure 1).

Interestingly, supplementation of rice straw hemicellulosic hydrolysate with ammonium sulfate and rice bran extract did not improve the xylose-to-xylitol bioconversion by the yeast Candida guilliermondii FTI 20037 in a single-batch fermentation (Silva, Roberto, 1999). On the other hand, supplementation of Eucalyptus (Canettieri et al., 2001) and wheat straw (Canilha et al.,
2005) hemicellulosic hydrolysates with the same nutrients showed to be beneficial for the bioconversion by the same yeast strain. The reasons for such a behavior are still not understood and suggest the necessity of additional experimentation.

As illustrated in Figure 2, it is clear that the supplementation of the SBHH with ammonium sulfate and rice bran extract speeds up the xylose consumption and the xylitol production by the cells throughout the repeated batches. Therefore, it is possible that the supplementation of the hydrolysate have provided the cells with essential precursors (vitamins and aminoacids) necessary to maximize the xylose consumption and, consequently, the production of xylitol. In this way, the higher xylitol production observed in Assay A should be attributed to the higher specific rates of xylose consumption. The profiles of xylose consumption and of xylitol production shown in Figure 3 seem to support this hypothesis.

The supplementation of fermentation media with different nutrients has been regarded as a factor that can influence the xylose-to-xylitol bioconversion. However, a consensus if they are either beneficial or detrimental can not be drawn (Winkelhausen, Kuzmanova, 1998; Parajó et al., 1998b). Generally, very high concentrations of nutrients stimulate cell growth, while a minimal optimal supplementation favors
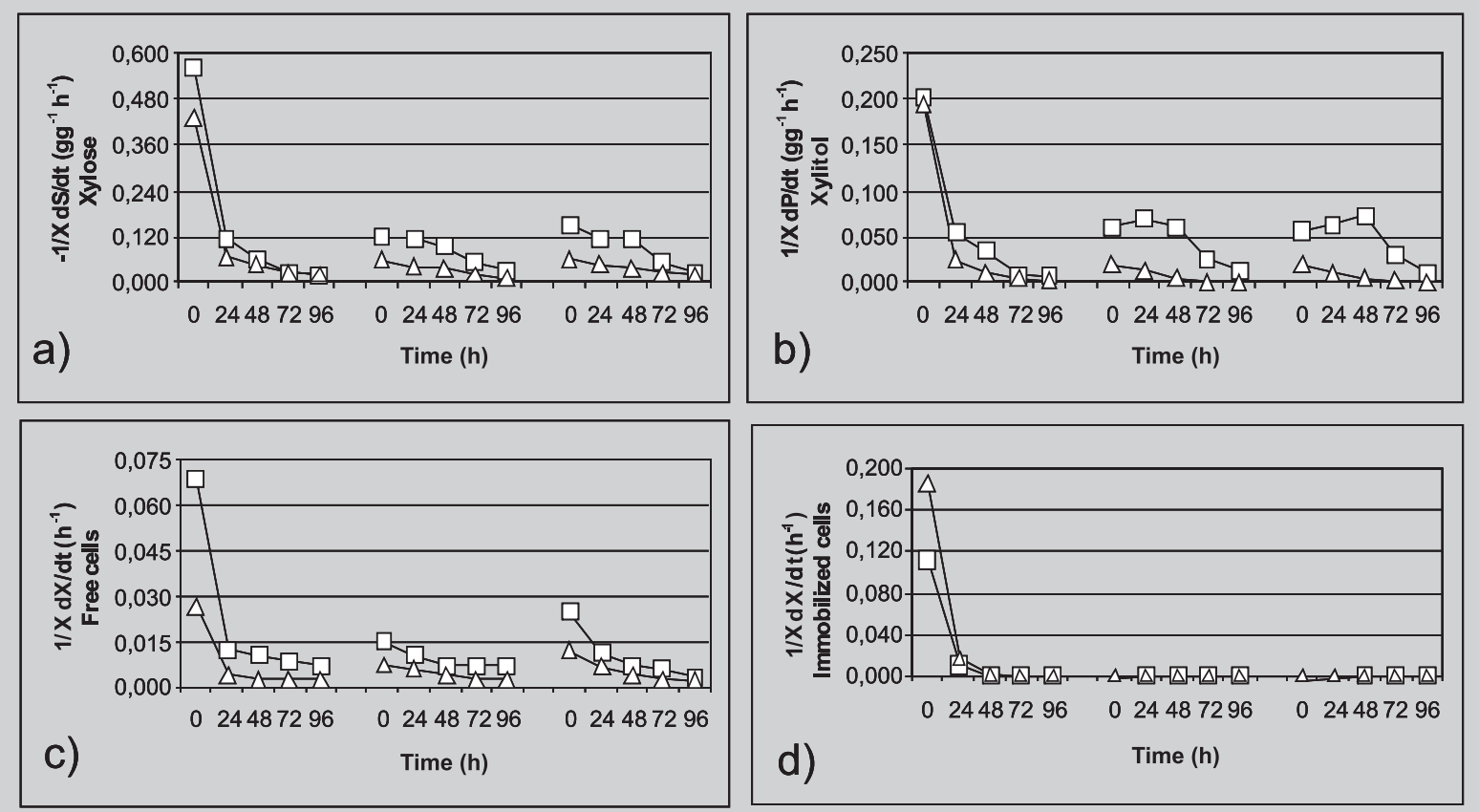

FIGURE 2 - Specific rates of xylose consumption (a), xylitol production (b) and cell growth (c,d) throughout the repeatedbatch fermentations: $\square$, supplemented hydrolysate (Assay A); $\triangle$, non-supplemented hydrolysate (Assay F). 


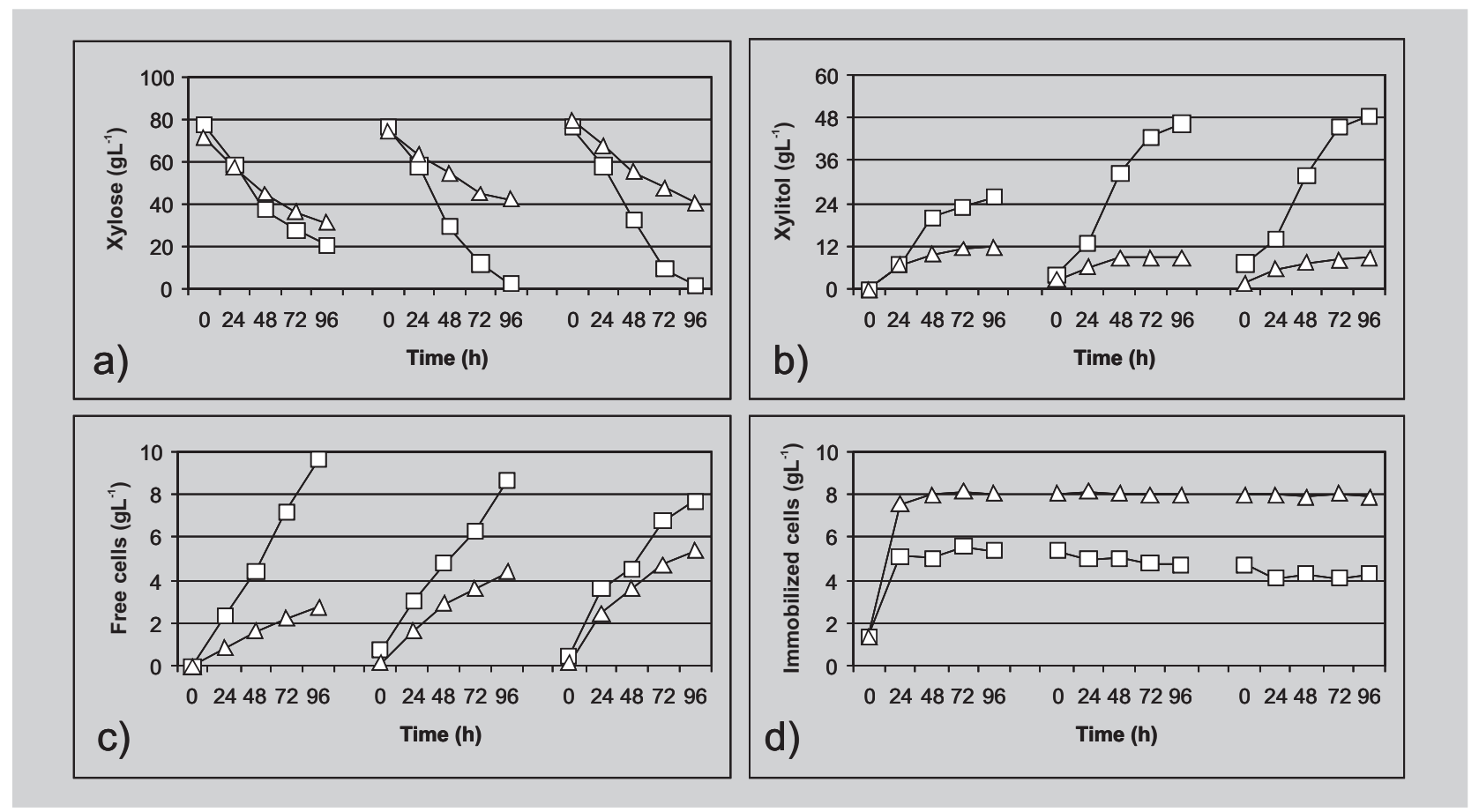

FIGURE 3 - Concentrations of xylose (a), xylitol (b) and cells (c,d) throughout the repeated-batch fermentations: $\square$, supplemented hydrolysate (Assay A); $\triangle$, non-supplemented hydrolysate (Assay F).

xylitol production (Silva et al., 1994; Sirisansaneeyakul et al., 1995; Silva et al., 1997). Considering the results achieved in the present study, the supplementation of the $\mathrm{SBHH}$ with both ammonium sulfate and rice bran extract should be performed throughout all the repeated batches in order to improve the xylose-to-xylitol bioconversion. In this context it is worth to point out that the rice bran extract can be easily prepared from rice bran, which is a by-product of rice processing and represents a cheap source of vitamins, fats and aminoacids (Demain, Solomon, 1986).

Last, but not least, as can be seen in Figures 2-3, the growth of free cells was always faster in the supplemented hydrolysate. Consequently, the concentrations of free cells at the end of the batches in Assay A (9.7, 8.7 and $7.8 \mathrm{gL}^{-1}$, respectively) were considerably higher than those observed in Assay F (2.8, 4.4 and 5.4 $\mathrm{gL}^{-1}$, respectively). Although the specific rates of immobilized cell growth did not differ greatly in the presence or absence of nutrients, the concentrations of immobilized cells observed at the end of the batches in Assay A (5.4, 4.7 and $4.3 \mathrm{gL}^{-1}$, respectively) were much lower than those observed in Assay F (8.1, 8.0 and 7.9 $\mathrm{gL}^{-1}$, respectively). Therefore, it seems that the supplementation of the SBHH with ammonium sulfate and rice bran extract influences the capacity of the Caalginate beads to retain the immobilized cells. A stronger growth of immobilized cells, leading to a pronounced cell leakage from the Ca-alginate beads, could explain such a behavior (Quirós et al., 1995).

\section{CONCLUSION}

The results presented in this study demonstrate that the nutritional supplementation of the SBHH with ammonium sulfate and rice bran extract improves the xylose-to-xylitol bioconversion by the yeast Candida guilliermondii FTI 20037.

\section{RESUMO}

\section{Bioprodução semi-contínua de xilitol em hidrolisado de bagaço de cana: efeito da suplementação nutricional}

A bioconversão de xilose em xilitol por células de Candida guilliermondii imobilizadas em alginato de cálcio, em hidrolisado hemicelulósico de bagaço de cana-deaçúcar, foi realizada em frascos erlenmeyer no modo bateladas repetidas de fermentação. O hidrolisado foi suplementado ou não com sulfato de amônio elou extrato de farelo de arroz no início de cada batelada repetida. No total, seis experimentos com três bateladas repetidas cada um foram realizados, sendo as células 
imobilizadas reutilizadas ao final de cada batelada. Os melhores resultados foram alcançados quando o hidrolisado foi suplementado com ambos nutrientes em todas as três bateladas repetidas, resultando em concentrações de xilitol iguais a 25,9, 46,8 e 48, $7 \mathrm{gL}^{-1}$, produtividades de 0,27, 0,49 e 0,51 $\mathrm{gL}^{-1} \mathrm{~h}^{-1}$, e rendimentos de $0,45,0,58$ e 0,55 $\mathrm{gg}^{-1}$, respectivamente. Na ausência de nutrientes, a concentração de xilitol, a produtividade e o rendimento não ultrapassaram $12,1 \mathrm{gL}^{-1}, 0,13 \mathrm{gL}^{-1} \mathrm{~h}^{-1}$ e $0.30 \mathrm{gg}^{-1}$, respectivamente.

UNITERMOS: Xilitol. Bagaço de cana-de-açúcar. Hidrolisado hemicelulósico. Fermentação em bateladas repetidas. Suplementação nutricional.

\section{ACKNOWLEDGEMENTS}

The authors gratefully acknowledge the financial support of FAPESP and CNPq.

\section{REFERENCES}

ALVES, L.A.; FELIPE, M.G.A.; ALMEIDA e SILVA, J.B.; SILVA, S.S.; PRATA, A.M.R. Pretreatment of sugarcane bagasse hemicellulose hydrolysate for xylitol production by Candida guilliermondii. Appl. Biochem. Biotech., v. 70-72, n. 1-3, p. 89-98, 1998.

BARBOSA, M.F.S.; MEDEIROS, M.B.; MANCILHA, I.M.; SCHNEIDER, H.; LEE, H. Screening of yeasts for production of xylitol from D-xylose and some factors which affect xylitol yield in Candida guilliermondii. $J$. Ind. Microbiol., v. 3, n. 4, p. 241-251, 1988.

CANETTIERI, E.V.; ALMEIDA e SILVA, J.B.; FELIPE, M.G.A. Application of factorial design to the study of xylitol production from Eucalyptus hemicellulosic hydrolysate Appl. Biochem. Biotech., v. 94, n. 2, p. 159$168,2001$.

CANILHA, L.; CARVALHO, W.; ALMEIDA e SILVA, J.B. Influence of medium composition on xylitol bioproduction from wheat straw hemicellulosic hydrolysate. World J. Microb. Biot., v. 21, n. 6-7, p. 10871093, 2005.

CARVALHO, W.; SILVA, S.S.; VITOLO, M.; FELIPE, M.G.A.; MANCILHA, I.M. Improvement in xylitol production from sugarcane bagasse hydrolysate achieved by the use of a repeated-batch immobilized cell system. Z. Naturforsch., v. 57c, n. 1-2, p. 109-112, 2002a.
CARVALHO, W.; SILVA, S.S.; CONVERTI, A.; VITOLO, M.; FELIPE, M.G.A.; ROBERTO, I.C.; SILVA, M.B.; MANCILHA, I.M. Use of immobilized Candida yeast cells for xylitol production from sugarcane bagasse hydrolysate: Cell immobilization conditions Appl. Biochem. Biotech., v. 98-100, n. 1-9, p. 489-496, 2002 b.

CARVALHO, W.; SILVA, S.S.; SANTOS, J.C.; CONVERTI, A.C. Xylitol production by $\mathrm{Ca}$-alginate entrapped cells: Comparison of different fermentation systems. Enzyme Microb. Technol., v. 32, n. 5, p. $553-$ $559,2003$.

CARVALHO, W.; SANTOS, J.C.; CANILHA, L.; ALMEIDA e SILVA, J.B.; FELIPE, M.G.A.; MANCILHA, I.M.; SILVA, S.S. A study on xylitol production from sugarcane bagasse hemicellulosic hydrolysate by Ca-alginate entrapped cells in a stirred tank reactor. Process Biochem., v. 39, n. 12, p. 2135-2141, 2004.

DEMAIN, A.L.; SOLOMON, N.A. Manual of industrial microbiology and biotechnology. Washington: American Society of Microbiology, 1986. 466 p.

LE DUY, A.; ZAJIC, J.E. A geometrical approach for differentiation of an experimental function at a point applied to growth and product formation. Biotechnol. Bioeng., v. 15, n. 6, p. 805-815, 1973.

MATTILA, P.T.; SVANBERG, M.J.; JAMSA, T.; KNUUTTILA, M.L.E. Improved bone biomechanical properties in xylitol-fed aged rats. Metab. Clin. Exp., v. 51, n. 1, p. 92-96, 2002

PARAJÓ, J.C.; DOMÍNGUEZ, H.; DOMÍNGUEZ, J.M. Biotechnological production of xylitol: Interest of xylitol and fundamentals of its biosynthesis. Bioresource Technol., v. 65, n. 3, p. 191-201, 1998a.

PARAJÓ, J.C.; DOMÍNGUEZ, H.; DOMÍNGUEZ, J.M. Biotechnological production of xylitol: Operation in culture media made from lignocellulose hydrolysates. Bioresource Technol., v. 66, n. 1, p. 25-40, 1998 b.

QUIRÓS, C.; RENDUELES, M.; GARCIA, L.A.; DIAZ, $M$. Diffusion of microorganisms in calcium alginate beads. Biotechnol. Technol., v. 9, n. 11, p. 809-814, 1995.

SILVA, S.S.; AFSCHARA.S. Microbial production of xylitol from D-xylose using Candida tropicalis. Bioprocess Eng.. v. 11, n. 4, p. 129-134, 1994. 
SILVA, S.S.; QUESADA-CHANTO, A.; VITOLO, M. Upstream parameters affecting the cell growth and xylitol production by Candida guilliermondii FTI 20037. Z. Naturforsch., v. 52c, n. 1, p. 359-363, 1997.

SILVA, C.J.S.M.; ROBERTO, I.C. Statistical screening method for selection of important variables on xylitol biosynthesis from rice straw hydrolysate by Candida guilliermondii FTI 20037. Biotechnol. Technol., v. 13, n. 11,p. 743-747, 1999.

SIRISANSANEEYAKUL, S.; STANISZEWSKI, M.; RIZZI, M. Screening of yeasts for production of xylitol from D-xylose. J. Ferment. Bioeng., v. 80, n. 6, p. 564$570,1995$.
UHARI, M.; TAPIAINEN, T.; KONTIOKARI, T. Xylitol in preventing acute otitis media. Vaccine, v. 19, n. 1, p. 144$147,2000$.

WINKELHAUSEN, E.; KUZMANOVA, S. Microbial conversion of D-xylose to xylitol. J. Ferment. Bioeng., v. 86, n. 1, p. 1-14, 1998.

Recebido para publicação em 13 de março de 2006. Aceito para publicação em 10 de outubro de 2006. 